\title{
Observations on the benthos of Murchison Bay, Lake Victoria, East Africa
}

\author{
J. Y. OKEDI \\ Department of Zoolog!: Makerere University. PO Box 7002. Keanpala, Uganda
}

\section{Sunimary}

There is paucity of data on benthic organisms in Lake Victoria, as in many other Alrican lakes. A study to ascertain the bicmess, standing crop and spatial distri-

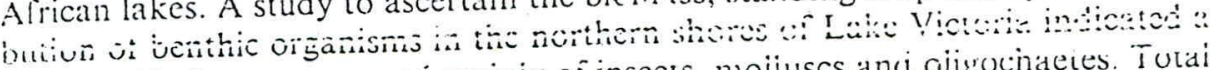
ricin benthic fauna composed mainiy of insects, moiiuses and oligocinaetes. Tutai biomass for the $200 \mathrm{~km}^{2}$ Murchison Bay was 146,000 tonnes. The lamellibranchs formed the highest biomass $(68,940 \mathrm{t})$ followed by gestropods $(30,840 \mathrm{t})$, insects $(25,760 \mathrm{t})$ and annelids $(20,460 \mathrm{t})$. Mean standing crop biomass values for gencra in the various taxa were determined from their spatial distribution patterns (mean numbers per unit area) and mean individual weights. The high benthic biomass is currently under-utilized by benthic organisms at higher trophic levels and consequently represents utilizable organic matter directly or indirectly for man's benefit. Hence, a lakewide study is recommended.

Key words: benthos, Lake Victoria, East Africa, bicmass.

\section{Résumé}

Ori possède peu de données sur les organismes benthiques du lac Victeria cemme de beaucoup d'autres lacs africains. Nienée dans le but de connaître la biomasse, Iinventaire et la distribution spatiale des organismes benthiques sur les bords nord du lac Victoria, unïétude a révélé une faune benthique riche, composée principalement d'insectes, de mollusques et d'oligochètes. La biomasse totale pour les $200 \mathrm{~km}^{2}$ de la Murchison Bay était de 146.000 tonnes. Les lamellibranches en composaient la plus grande part $(68,940 \mathrm{t})$, suivis par les gastéropodes $(30,840 \mathrm{t})$,

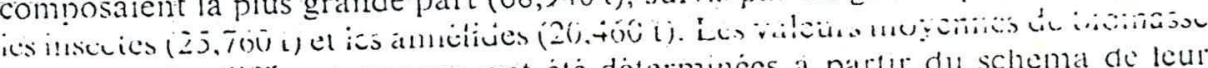
pati genre des diflërents taxons ont éte determinécs a partur du schema de leur distribution spatiale (nombres moyens par unité de surface) et du poids individuel moyen. La biomasse benthique élevée est actuellement sous-utilisée par les organismes benthiques des ordres trophiques supérieurs et représente par conséquent une matière organique directement ou iidirectement utilisable au profit de l'homme. On recommande donc une étude à l'échelle du lac entier.

\section{Introduction}

Lake Victoria has a total area of $66,500 \mathrm{~km}^{2}$ with mean depth of $40 \mathrm{~m}$ and maximum depth of $79 \mathrm{~m}$. It lies between longitude $30^{\circ} 30^{\prime} \mathrm{E}$ and $34^{\circ} 31^{\prime} \mathrm{E}$ and 


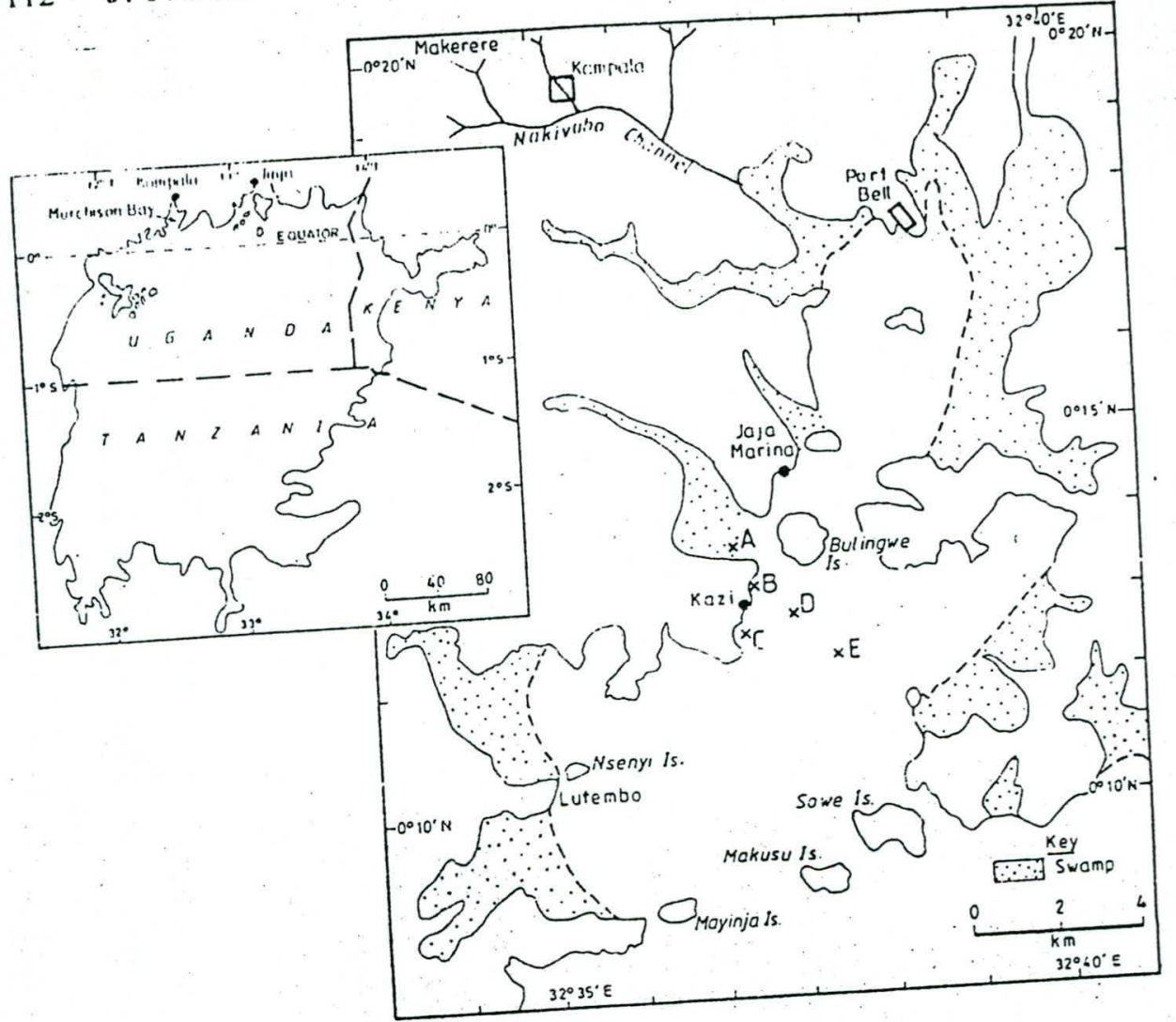

Fig. 1. Map of Murchison Bay, Lake Victoria.

latitude $00^{\circ} 30^{\prime} \mathrm{N}$ and $02^{\circ} 31^{\prime} \mathrm{S}$. It is the second largest lake in the world and is shared betivecn Kenya, Uganda and Tanzania (Fig. 1).

is located in the northwestern part of the lake in Uganda, some $14 \mathrm{~km}$ from Kampala City. The Bay has an area of about $200 \mathrm{~km}^{2}$ with a shoreline length of $124 \mathrm{~km}$ and a mean depth of $8 \mathrm{~m}$. It lies betwtitude of $1154 \mathrm{~m}$. The Bay $32^{\circ} 41^{\prime}$ East and latitude $00^{\circ} 05^{\prime}$ and $00^{\circ} 18^{\prime}$ North at anceni, Mayinja, Makusu and has several small islands including Sulinguge mud near fringing vegetation and Sowe. The bottom is predominant the bottom of Murchison Bay is mainly sandy, a rock near rocky shores. Although the adjacent to papyrus and this was the main thick layer of debris is found in areas adjaddy material derived from vegetable area of sampling as it consisted of mu are surrounded by forests but within the decomposition. Here the papyrus swamps are The predominant fringing vegetation swamp water lilies float in open water spaces. Thepres communis. Further inland are type is Cyperus papyrus, C. rotundus and emini, Lovoa brownii and Ficus mucuso. on ichthyological studies (Corbet,

Past workers in Lake Victoria concentrat 155. Macdonald, 1956, Corbet et ál., 1961; Greenwood, 1960). Hartland-Rowe, Hironomidae, Chaoboridae and Povilla 1955; and Corbet, 1958 studied lakeflies (Chironomidat Ephemeroptera) and showed lunar periodicity in their patterns of emergence 
in Lake Victoria. Pliytoplankton has been extensivcly studied (Talling, 1965, 1966: Beedle, 1974; and Visser. 1974) and Ochumba \& Kibalara (1989). amongst others. have revealed tendencies towards algal blooms in the lake. Yet these are important trophic segments in the trophic relations of the lake. playing a major role in feeding ecology and nutrient recycling between autorrophs and heterotrophs. This study is one of the first attempts to quantify benthic organisms in Lake Victoria. The biomass and patterns of distribution of benthic invertebrates (Insecta, Mollusca and Annelida) were studied in a shallow bay in the northern portion of the lake.

Materials and methods

Five sampling stations were established along the Kaizi area of Murchison Bay and were sampled regularly twice-monthly from. November 1987 for six months. Station A was near the shore, fringed by Cyperus papyrus in water about $1.5 \mathrm{~m}$ deep. Station B (1.5 m water depth) was fringed by Cyperus rotundus. Station C ( $1.5 \mathrm{~m}$ water depth) was fringed by Phragmites communis. The water column l:cet was dominated by dead fibrous vegetable matter and the bottom was compusede uf rotting macrophytic material in varying stages of decomposition. Station $D$ was an. offshore station $500 \mathrm{~m}$ from the shore in clear open water about $8 \mathrm{~m}$ deep but with muddy bottom. The substratum here was composed of flocculent dark grey mud with little or no vegetable matter. Station E, also offshore and $500 \mathrm{~m}$ from Station? D. had a sandy bottom at a depth of $8 \mathrm{~m}$. The sand was mainly fine-grained and brown in colour mixed with some fine greyish silt.

Pieces of fresh rotting vegetation types were cut out from the fringing vegetation and kept in separate buckets before being weighed and carefully split open. The insect larvae boring into the plant material were identified with the aid of a binocular microscope, weighed and preserved in $5 \%$ formaldehyde solution.

Bottom samples from Station A, D and E were collected using an E $\$ \mathrm{kman}$ dredge with an opening of $225 \mathrm{~cm}^{2}$. Two dredges from each station were usually taken as standard, and their contents, often mud, sand or debris, were emptied into separate numbered buckets. In the laboratory the samples were sieved several times through progressively finer meshed sieves $(0.6,0.5,0.2$ and $0.075 \mathrm{~mm})$ to reduce bulk. The invertebrates retained in the sieves were sorted, identified and counted at species level and weighed with a Mettler balance after partial drying on filter paper.

\section{Observations}

Povit!a adustci

Fovilla nymphs were collected from three main host plants, Cyperus papyrus, $C$. rotundus and Phragmites communis in Stations A, B and C. The numbers and weight of Povilla caught per sampling day are given in Table 1 for each host plant. The largest number of nymphs caught was 49 in C. papyrus and the fewest was 3 in Phragmites. The largest number of Povilla caught were found in Cyperus papyrus (226) but the lowest number (41) in Phragmites. This may perhaps indicate a habitat preference of Povilla over Cyperus papyrus, moderate attraction for $C$. rotundus and least preference for Phragmites. However, a piece of dried submerged wood carried 729 nymphs (Table 1) giving the highest density of nymphs collected during this study. 
Table 1. Numbers of Povilla caught per $\mathrm{kg}$ host plant material with their biomass (b) in purentlieses

\begin{tabular}{lrrr}
\hline Plant host & $\begin{array}{r}\text { Number } \\
\text { per kg }\end{array}$ & & Percentage \% \\
\hline Cyporus papyrus & 32 & $(4.992)$ & $4 \cdot 1$ \\
C. rotundus & 16 & $(2.486)$ & 2.0 \\
Phragmites comminis & 6 & $(0.936)$ & 0.8 \\
Dried plank & 729 & $(113.724)$ & 93.1 \\
\hline
\end{tabular}

It is interesting to note that calculated as a percentage of host material, $11 \%$ of the weight of the plant material was made up of Povilla nymphs, whereas they formed only $0.5 \%$ of submerged $C$. papyrus, $0.25 \%$ of $C$. rotundus and only $0.1 \%$ of submerged Phragmites. These figures can be used as a guide to estimate Povilla biomass in certain submerged woody materials. However, Povilla biomass in submerged logs is related to the state of decomposition of the host material.

Povilla was also collected with the Edkman dredge, from the muddy bottom of Station A and D (Table 2) and a few from the sandy bottom of Station E. In the Bay as a whole the Povilla formed $30 \%$ of all the benthic insects as shown in Fig. 2 with $15 \%$ occurring in Station A, $14 \%$ in Station D and $1.3 \%$ in Station E. This indicates that Povilla nymphs are found also in the benthos away from the fringing vegetated zone of the Bay. Their biomass has been calculated based on a mean fresh weight of 0.15 per individual (Table 3), as $40 \mathrm{~g} \mathrm{~m}^{-2}$ (Table 4). Their total biomass for the Bay is shown in Fig. 3 as 7920 t. This composition, however, does account for Povilla boring into plant material both along the shore and submerged in the Bay.

\section{Chironomidae}

Chironomids were the most abundant insect larvae in both inshore and offshore station. The mean number was $978 \mathrm{~m}^{-2}$ in Station $A, 765 \mathrm{~m}^{-2}$ in Station D and $265 \mathrm{~m}^{-2}$ in Station E (Table 2). Chironomids made up $63 \%$ of all the benthic insects in the Bay (Fig. 2). However, 30\% occurred in Station A, $24 \%$ in Station D and $8.5 \%$ in Station E. It becomes apparent at this stage that the chironomids prefer a mud bottom.

With a mean weight of $0.12 \mathrm{~g}$ (Table 3) the mean standing crop biomass of the Chironomidae was calculated as $\mathrm{g} 80 / \mathrm{m}^{2}$ (Table 4). However, Station A had a biomass of $117 \mathrm{gm}^{-2}$, Station D $92 \mathrm{gm}^{-2}$ and Station E $32 \mathrm{~g} \mathrm{~m}^{-2}$. For the whole Bay, the chironomid biomass was estimated at 16,060 t constituting $11 \%$ of aii the organisms in the Bay (Fig. 3).

\section{Chaoborus larvae}

The mean numbers of Chaoborus per square metre are given in Table 2 as 25 for Station A, 38 for Station $D$ and 12 for Station $E$. The mean weight of an individual was $0.13 \mathrm{~g}$ (Table 3). Its standing crop in $\mathrm{g} \mathrm{m}^{-2}$ was 3 for Station A, 5 for Station D and 1.6 for Station E (Table 4). The chaoborids made up less than $2 \%$ of the benthic insects, $1.2 \%$ of which occuried in Station D. Both Station A and E made up less than $1 \%$ of all the organisms shown in Fig. 3. 
Table 2. Mean numbers of organisms caught per $\mathrm{m}^{2}$ in threc stations in Murchison Bay

\begin{tabular}{|c|c|c|c|}
\hline Class & Station A & Station D & Station $\mathrm{E}$ \\
\hline Lamellibranchs & (103) & $(219)$ & (130) \\
\hline Mutcla & 2 & $\begin{array}{r}2 \\
175\end{array}$ & 23 \\
\hline Pisidium & 59 & 175 & \\
\hline Caelatura & 42 & 42 & 2 \\
\hline Gastropoda & (205) & (291) & (36) \\
\hline Bellamya & 108 & 206 & 28 \\
\hline Mellanoides & 17 & 76 & 8 \\
\hline Biomphalaria & 70 & 3 & 0 \\
\hline Bulinus & 10 & 6 & 0 \\
\hline Insecta & $(1412)$ & $(1186)$ & (317) \\
\hline Povilla & 382 & 377 & 32 \\
\hline Chironomidae & 978 & 765 & 265 \\
\hline Chaoborus & 25 & 38 & 12 \\
\hline Odonata & 21 & 3 & $\mathscr{\&}$ \\
\hline Belastume & 6 & 3 & 0 \\
\hline Annelida & (301) & $(41)$ & $(624)$ \\
\hline Oligochaeta & 288 & 41 & 624 \\
\hline \multirow{2}{*}{ Hirudinea } & 13 & 0 & 0 \\
\hline & 2021 & 1737 & 1107 \\
\hline
\end{tabular}

\section{Odonata nymphs}

The distribution of the Odonata is mainly inshore (Table 2), with $21 \mathrm{~km}^{-2}$ being caught in Station A, 3 in Station D and 8 in Station E. In all the three stations they composed $1 \%$ of all the organisms. Amongst the insects, the Odonata were les $3 \%, 2 \%$ of which occurred in Station A. Sixty-five percent of all the (nowerer, Odonata nymphs specimens were found in the she $0.35 \mathrm{~g}$ (Table 3). Their standing crop $\left(\mathrm{g} \mathrm{m}^{-2}\right)$ was are heavy, with a mean weight in the Bay (Fig. 3).

\section{Belostome larvae}

The composition of Belostome larvae was low, 6 in Station A, 3 in Station D and none in Station E. Table 2 shows this genus as predominantly prefering a mud bottom; $66 \%$ in Station A alone and $34 \%$ in Station $\mathrm{D}$. The mean biomass was almost $2 \mathrm{~g} \mathrm{~m}^{-2}$ (Table 4) giving a biomass of $380 \mathrm{t}$ for Murchison Bay as a whole (Fig. 3).

Thus benthic insects made up $18 \%$ of the total biomass of benthic invertebrates in the Bay (Fig. 4). However, Station A contained their largest biomass, 33\%, with Station D at $26 \%$ and Station E just $4: 2 \%$.

\section{The Lamellibranchs}

Lamellibranch molluscs occurred in three stations; $103 \mathrm{~m}^{-2}$ in Station A, $219 \mathrm{~m}^{-2}$ in Station D and $130 \mathrm{~m}^{-2}$ in Station $\mathrm{E}$ (Table 2). However, they tended to prefer the muddy offshore Station D where $48 \%$ of them occurred. Only $22 \%$ were found in 


\section{$\cdot 116$ \\ J. Y. Okedi}

\section{Lamellibranchs}
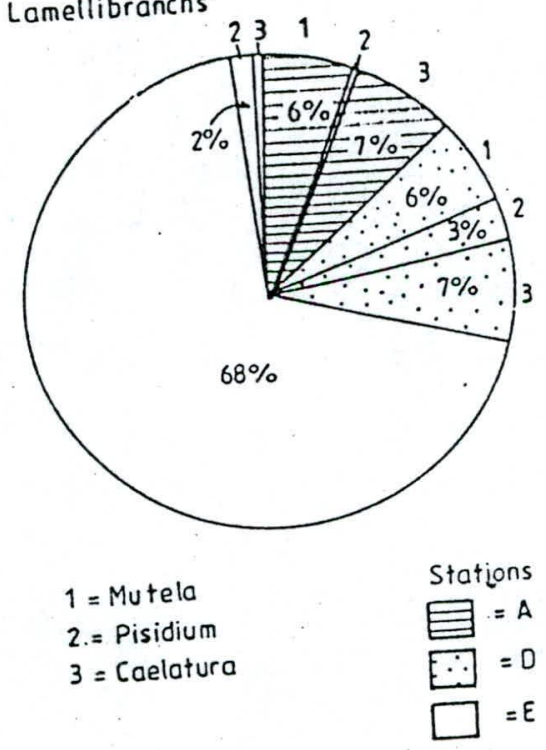


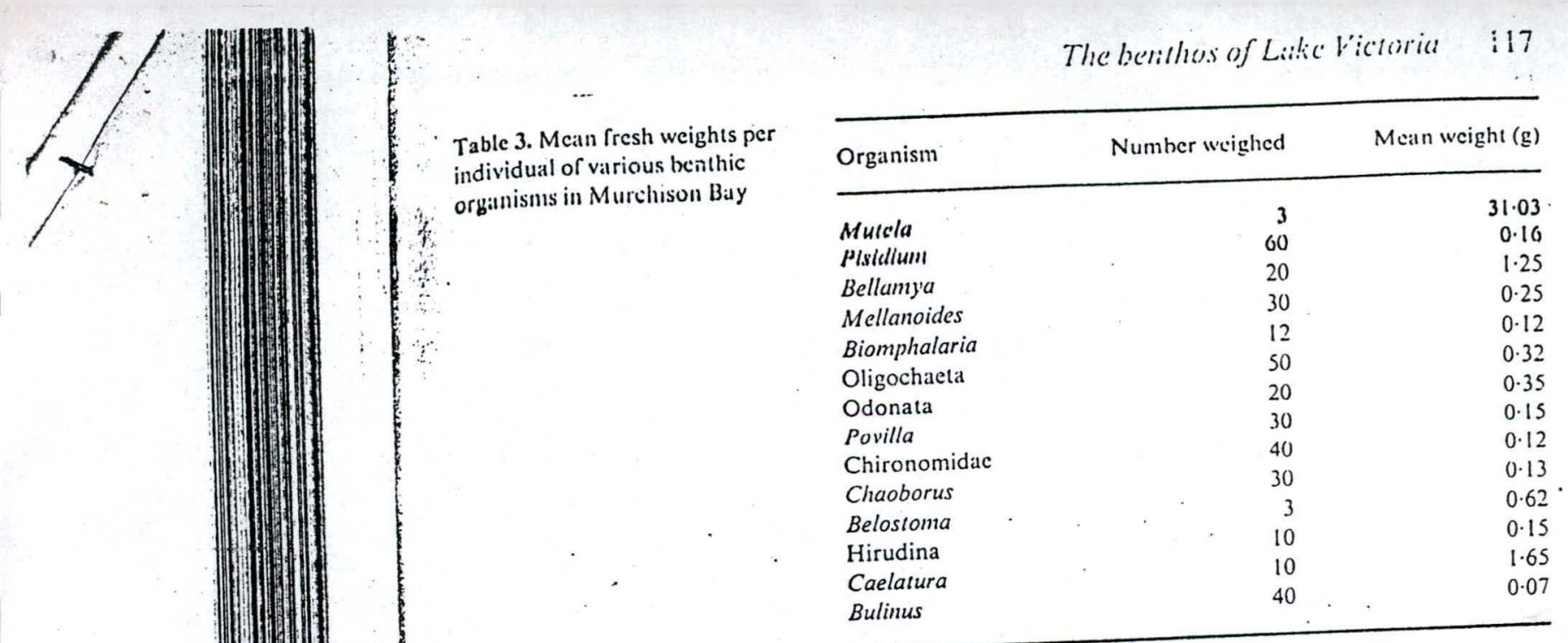
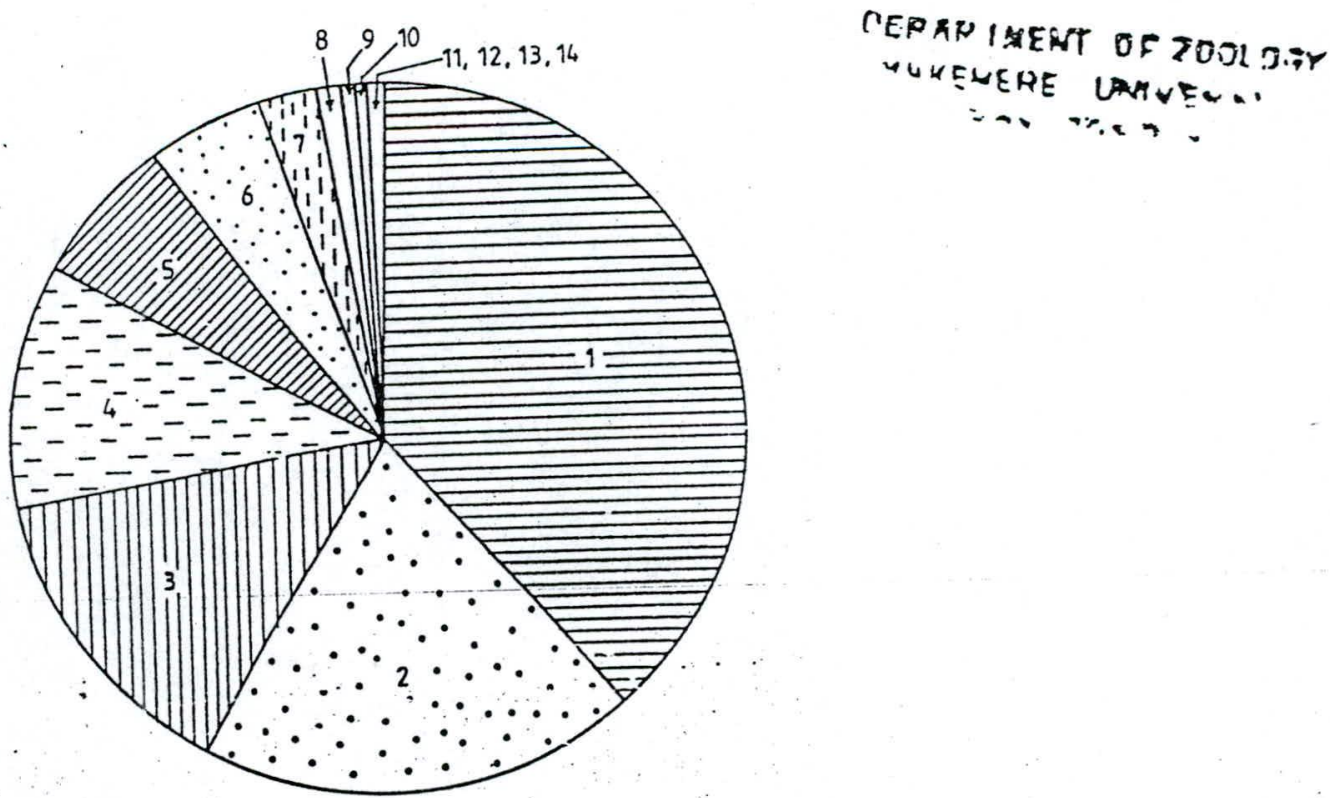
1. Mutelo
$=558060 \mathrm{~m} \cdot \mathrm{t}$
8. Mellanoides
$=1680 \mathrm{~m} \cdot \mathrm{t}$
2. Bellamya
9. Odonata
3. Oligochoeta
$=28500$ "
10. Chaoborus
$=740$.
4. Chironomidae
$=20320$
11. Biomphalario
$=660$.
. Caelatura
12. Belastome
$=580$.
$=16060 "$
6. Povillo
$=7920$.
13. Hirudinea
$=380$ "
7. Pisidium
14. Bulinus
$=140$.
$=3620$.
$=80$

Fig. 3. Biomass ( $t$ ) of the major taxa of benthic communities in Murchison Bay. 
Table 4. Mcan standing crop biomass $\left(\mathrm{g} \mathrm{m}^{-2}\right)$ from threc stittions in Murchison Bay. $\mathrm{T}=$ Iotul bioniass neross the three klutionis

\begin{tabular}{|c|c|c|c|c|}
\hline & $\wedge$ & D & $\begin{array}{r}\text { Stations } \\
E\end{array}$ & $\begin{array}{r}\text { Mean } \\
\text { biomass }\end{array}$ \\
\hline \multicolumn{5}{|l|}{ I,wmellithranclix } \\
\hline Murcla & $62 \cdot 1$ & 02.1 & 713.7 & 279.3. \\
\hline Pisidium & $9 \cdot 4$ & $28 \cdot 0$ & $16 \cdot 8$ & 18.1 \\
\hline \multirow[t]{2}{*}{ Caclatura } & $69 \cdot 3$ & $69 \cdot 3$ & $3 \cdot 3$ & $47 \cdot 3$ \\
\hline & $140 \cdot 8$ & $159 \cdot 4$ & 733.8 & $(T=1034)$ \\
\hline$(1 / 1)$ & $(13 \cdot 6)$ & $(15.41)$ & $(70 \cdot 1)$ & \\
\hline \multicolumn{5}{|l|}{ Gastropoda } \\
\hline Bellamya & $135 \cdot 0$ & $257 \cdot 5$ & $35 \cdot 0$ & 142.5 \\
\hline Mcllanoides & $4 \cdot 3$ & $19 \cdot 0$ & $2 \cdot 0$ & $8 \cdot 4$ \\
\hline Biomphalaria & $8 \cdot 4$ & 0.4 & 0 & $2 \cdot 9$ \\
\hline \multirow{2}{*}{ Bulinus } & 0.7 & 0.4 & 0 & 0.4 \\
\hline & $148 \cdot 4$ & $277 \cdot 3$ & $3.7 \cdot 0$ & $(T=462)$. \\
\hline$(\%)$ & $(32 \cdot 1)$ & $(60 \cdot 0)$ & $(8 \cdot 0)$ & \\
\hline \multicolumn{5}{|l|}{ Annelida } \\
\hline Oligochaeta & $92 \cdot 2$ & $13 \cdot 1$ & $199 \cdot 7$ & $101 \cdot 6$ \\
\hline \multirow[t]{2}{*}{ Hiirudinea } & $2 \cdot 0$ & 0 & 0 & 0.7 \\
\hline & $94 \cdot 2$ & $13 \cdot 1$ & $199 \cdot 7$ & $(\mathrm{~T}=307)$ \\
\hline$(\%)$ & $(30 \cdot 6)$ & $(4 \cdot 3)$ & $(65 \cdot 1)$ & \\
\hline \multicolumn{5}{|l|}{ Insecta } \\
\hline Povilla & $57 \cdot 3$ & $56 \cdot 6$ & $4 \cdot 8$ & $39 \cdot 6$ \\
\hline Chironomidae & $117 \cdot 4$ & 91.8 & 31.8 & $80 \cdot 3$ \\
\hline Chaoborus & $3 \cdot 2$ & 4.9 & 1.6 & $3 \cdot 3$ \\
\hline Odonaia & $7 \cdot 4$ & $1 \cdot 1$ & 2.8 & $3 \cdot 7$ \\
\hline \multirow[t]{2}{*}{ Bclastome } & $3 \cdot 7$ & 1.9 & 0 & 1.9 \\
\hline & $189 \cdot 0$ & $156 \cdot 3$ & $41 \cdot 0$ & $(\mathrm{~T}=386)$ \\
\hline$(\%)$ & $(49 \cdot 0)$ & $(40 \cdot 5)$ & $(10 \cdot 6)$ & \\
\hline
\end{tabular}

Similarly Mutela was well represented in the sandy offshore Station E (23 $\mathrm{m}^{-2}$ - Table 2); both the shallow muddy Station A and offshore Station $D$ had very few Mutela $\left(2 \mathrm{~m}^{-2}\right)$. However, Mutela is a very heavy Lamellibranch with a mean weight of $31 \mathrm{~g}$. Therefore, its mean standing crop (Table 4) was $279 \mathrm{~g} \mathrm{~m}^{-2}$, although Station E contained its highest standing crop $\left(713 \mathrm{~g} \mathrm{~m}^{-2}\right)$ with only. $62 \mathrm{~g} \mathrm{~m}^{-2}$ in the other station. Mutela had therefore a total biomass of 55,860 in the Bay (Fig. 3) and this was $38 \%$ of the biomass of all the invertebrates.

Caelatura, on the other hand, showed marked preference for the muddy bottom, $42 \mathrm{~m}^{-2}$ in both Station $A$ and Station D, but only $2 \mathrm{~m}^{-2}$ in Station E (Table 2). However, Caelatura is a light lamellibranch with a mean weight of $1.65 \mathrm{~g}$, giving a standing crop per $\mathrm{m}^{2}$ (Table 4 ) of $47 \mathrm{~g}$. Caelatura has therefore a moderate biomass of 9460 tin the Bay (Fig. 3) which was $6.5 \%$ of the total biomass of all the organisms in the Bay. 


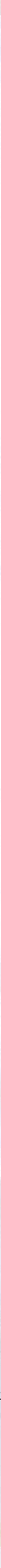


Three other gastropods occurred in the Bay, namely Mellanoides, Biomphalaria and Bulinus. The last two genera are important secondary hosts of Schistosoma memssoni and S. haematobium (Bendle, 1974). Schistosomen northern shores of Lake of billarzia, which is a common here, however, reveal that both bilharzia-carrying Victoria. Observations made the shallow inshore waters (Table 2) and that snails are largely restremon than Bulinus-hence the prevalence of intestinal Biomphalaria is more com Biomphalaria) as opposed to the urinary type billharzia Schistosomiasis (carried bulinus.

phalaria per $\mathrm{m}^{2}$ were found in Station $A$ but only

Table 2 shows that 70 Biomphalaria per $m^{2}$ were found in the offshore sandy

$3 \mathrm{~m}^{-2}$ were found in Station D. No Biompt built snail, mean weight $0.12 \mathrm{~g}$ (Table bottom Station E. Biomphalaria is a ligh $8 \mathrm{~g} \mathrm{~m}^{-2}$ in Station D (Table 4). Thus, its 3). Biomphalaria has a standing crop $\mathrm{g} \mathrm{m}^{-2}$ but total biomass was $380 \mathrm{t}$ (Fig. 3). mean standing crop for the Bay is was much lower $\left(10 \mathrm{~m}^{-2}\right)$ in Station $A$ and

The concentration of Bulinus was much the deeper offshore sandy bottonStation $\mathrm{D}\left(6 \mathrm{~m}^{-2}\right)$. No Bulinus occurrean weight $\left.0.07 \mathrm{~g}\right)$ giving a standing crop of Station E. Bulinus is a very light snal (m $\mathrm{m}^{-2}$ in Station D (Table 4). Its total biomass just $0.7 \mathrm{~m}^{-2}$ (in Station A) and $04 \mathrm{t}$ (Fig. 3).

The other gastropod encountered was Mellanoides occurring at levels of $7 \mathrm{~m}^{-2}$ (Station A), $76 \mathrm{~m}^{-2}$ (Station D) and only $8 \mathrm{~m}^{-2}$ (Station E). At a mean weight of $0.25 \mathrm{~g}$ (Table 3) this genus gave a standing crop of $8.4 \mathrm{~g} \mathrm{~m}^{-2}$ and a total biomass of $1680 \mathrm{t}$ for the whole Bay (Fig. 3). However, $75 \%$ of this biomass occurred in the mud bottom offshore Station $\mathrm{D}$.

\section{Annelida}

Two groups of annelids were encountered in Murchison Bay. The blood-sucking Hirudinea worms occurred at a very low level of $13 \mathrm{~m}^{-2}$ (Table 2 ) in the shallow inshore Station A only; none was found offshore. However, the annelids as a whole made up $16 \%$ of the biomass of the invertebrates in Station formed $14 \%$ of the and only $2 \%$ in Station D. However, in total, the annel.

biomass of all the benthic inv was the oligochaete blood worm which occurred in all

The major annelid found was the offshore sandy bottom Station E carried the highest density the three stations. The offshore sal wo common in the shallow inshore Station A $\left(624 \mathrm{~m}^{-2}\right)$, but blood worms wertom Station $\mathrm{D}$ had only $\left.41 \mathrm{~m}^{-2}\right)$. The oligochaete $\left(301 \mathrm{~m}^{-2}\right.$ ) (the offshore weight of $0.32 \mathrm{~g}$ and they had a standing crop of $102 \mathrm{~g} \mathrm{~m}^{-2}$ worms had with total biomass estimated at $20,320 \mathrm{t}$ (Fig. 3) for the whole Bay.

\section{Discussion}

In several studies of African lakes emphasis has been on the study of fish and limnological conditions. What little has been studied on benthos has included works related to biology, emergence and colonization of artificial substrata (e.g. Hartland-Rowe, 1955; Corbet \& Tjonneland, 1955; McDonald, 1956; Corbet, Hartland-Rowe, 1955; Cor 1958 ; Burgis et al., 1973; Hare \& Olisedu, 1987). The limnology of Lake Victorion we
has been well documented with the foundation works of Talling $(1965,1966)$, Beadle (1974) and Visser (1974). 
The patucity of data on the benthes and substratum is thercforc evident. Yet in with the lake bottom, both in terms of chemical zone are in constant interchange well as constant biotal interaction. There are or ionic exchange of nutrients as specialize in utilizing and exploiting the are many benthic organisms which sheler. These bollom organisms play ame benthic zone for food, breeding and nutrients from the lake bottom back into limajor role in activating the release of of the ecosystem is vital for the sustenance of the ouch unit or trophiclevel plays a major role but its significance has been the others. The benthos therefore

methodology of its sampling and assessment.

has been a tendency toward diminishing fish cat typifies many African lakes. There of certain endemic haplochromiine (Wanik catches marking the virtual extinction introduction of the voracious predator Lates al., 1988) and tilapiine species. The had a detrimental effect on pollution (Awiti, 1984) in certain bays. There conditions have deteriorated due to stand what changes are taking place in the lake and how la urgent need to uncierreacting to those changes. For example is Lake Victoria fare flora and fauna are cutrophic? At what rate and what are the Lactors Victoria increasingly becoming biota consequently changing rapidly in favour causing eutrophication? Is the species? Evidently further studies are needed.

Some organisms inhabiting are needed.

abundant but have hitherto not beenthic zone of Lake Victoria are very lakefly swarm in great numbers. The molluscs utilized for man's benefit. The oligochaete worms are plentiful. The data given are there in great quantities. The of what is available for human exploitation given the gre positive and give an idea fish stocks and fall in available protein. Furthermor glum picture of diminishing abundant and widespread but appear to formore, the oligochaete worms are Previous studies on feeding habits of fish form an under-utilized trophic level. these worms (Corbet, 1961). The worms are primarily benthormyridae feed on thus restricting their capture by fish. A study to identify and and mud-dwelling species capable of utilizing oligochaete worms identify and cncourage other fish mounted:

\section{References}

Awm, D. (1984) Pollution in the Lake. Report from the-Municipality of Kisumu, Kenya

BEtOLE, L.C. (1974) The Inland Waters of A frica. Longman, London.

biomass and distribution of organisms in Lake George, Uganda. Proc. R. Sü. Lond, L.iM. (1973) The

CokRer, P.S. $(1950)$ Lunar periodicity of aquatic insects in Lake Victoria. Ra. Sü. Lond. B. 184, 271-298.

Cerser, E.S. (i 961 ) The food of non cichlid fishes in the Lake Victoria basin with 182, 330-331.

and adaptation to lacustrine conditions. Proc. zool. Soc. Lond 136 , 1-10 temarks on their evolution

Carbet, P.S. \& Tuonneland, A. (1955) The flight act. Soc. Lond., 136, 1-101.

insects. Nalure 175, 1122 .

GexinvoOD P H (1960) The Fis

Huxe, L. \& Ousedu, N.M. (1987) Substrate Uganda. The Uganda Society, Kampala.

Navas (Epiemoroptera, Polymitercyidae). Aquatic Insects $9,145-154$.

Haxinand-Rowe, R. (1955) Lunar rhythm in Aquatic Insects 9, 145-154.

Lagroet W. (1988) The Nile Perch in Lake Victoria: a Blessing or an Ephemeropteran. Nature 176, 657.

Fue Netherlands. 


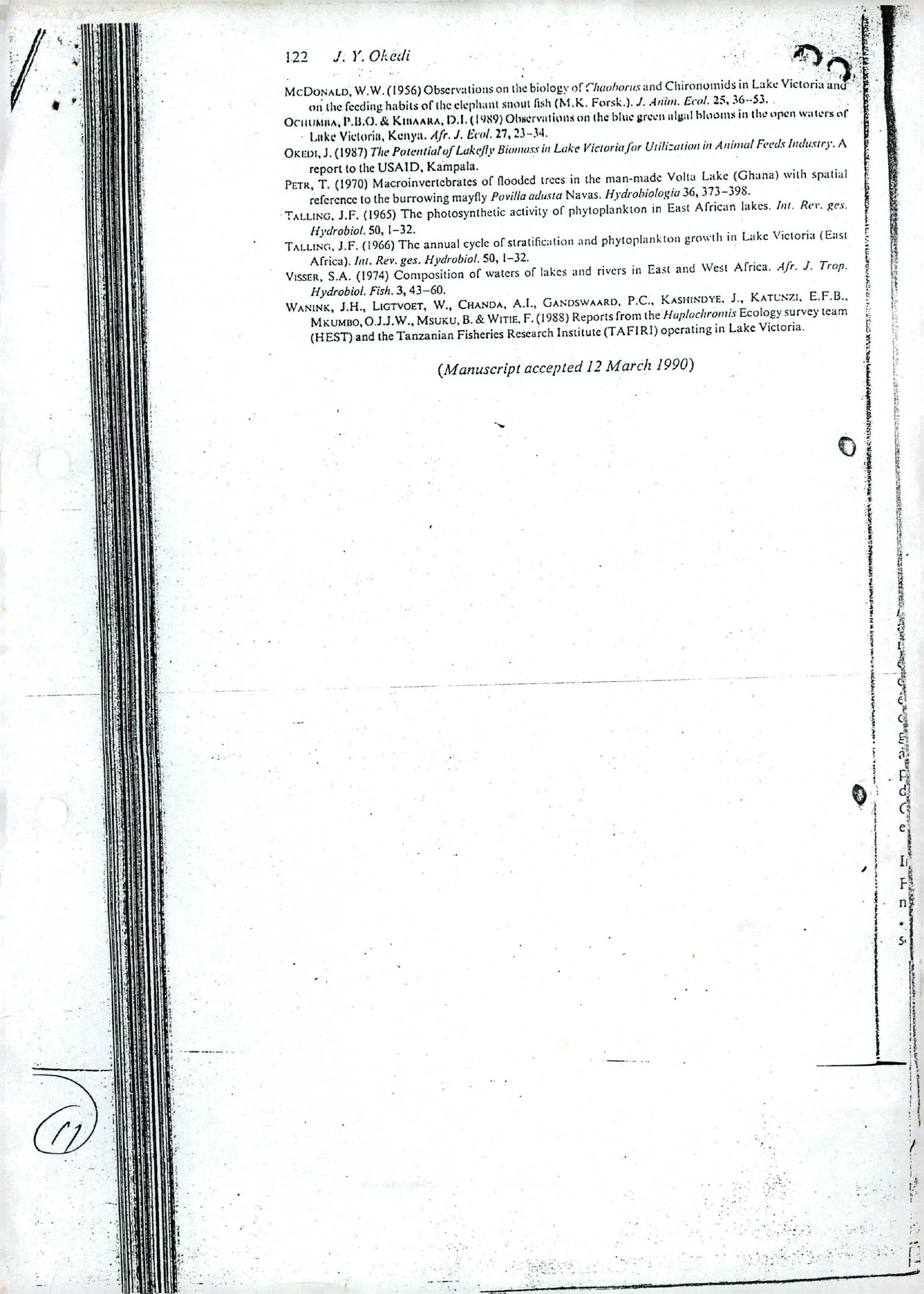

